TITLE:

\title{
Diverse local regulatory responses to a new forestry regime in forest communities in the Bolivian Amazon
}

\section{AUTHOR(S):}

Cardona, Walter Cano; de Jong, Wil; Zuidema, Pieter A.; Boot, Rene

\section{CITATION:}

Cardona, Walter Cano ... [et al]. Diverse local regulatory responses to a new forestry regime in forest communities in the Bolivian Amazon. Land Use Policy 2014, 39: 224-232

\section{ISSUE DATE:}

2014-07

URL:

http://hdl.handle.net/2433/188740

\section{RIGHT:}

(c) 2014 Elsevier Ltd. Published by Elsevier Ltd.; この論文は出版社版で ありません。引用の際には出版社版をご確認ご利用ください。; This is not the published version. Please cite only the published version. 


\title{
Diverging Regulatory Responses to a New Forestry Regime in Forest Communities in the Bolivian Amazon
}

\author{
Walter Cano Cardona14, Wil de Jong2, Pieter Zuidema34, and Rene Boot1,4
}

1 Tropenbos International, Wageningen Netherlands

2 Center for Integrated Area Studies, Kyoto University, Japan

3 Forest Ecology and Forest Management Group, Wageningen University and Research Center

4 Ecology \& Biodiversity group, Institute of Environmental Biology, Utrecht University, Netherlands

\begin{abstract}
Over the last decade, important decentralization processes and agrarian reforms have taken place in many tropical countries, with the purpose of transferring rights and responsibilities to forest communities. These reforms have resulted in an intensive academic debate on governance and management of forests and how actors should be involved. An important but understudied element in this debate is the way in which communities cope with new legislation and responsibilities. Property rights bestowed by the government leave many aspects un-decided and require that local forest users devise principles of access and allocation and establish authority to control those processes. We studied 16 communities in the northern Bolivian Amazon to evaluate how forest communities develop and control local rules for resource access and use. We found that the first requirement to community rule design, enforcement, and effective forest management is the opportunity to, and equity of, access to forest resources among members. Under the newly imposed forestry regulations, communities took matters in their own hands, and designed more specific rules rights and obligations of how community members could and should use economically important resources. The cases suggest that communities maintain capacity to prepare their own ownership arrangements and related rules, even if they are strongly conditioned by the regulatory reforms. Very specific local histories, that may differ from community to community, influence strongly how specific ideas are being shaped, which in northern Bolivia resulted in notable local differences. The results suggest that new regulatory regimes should consider options that given the adequate conditions, communities can define adequate or at least convenient forestry institutions that assure an acceptable level of collective coexistence according to each particular communal history.
\end{abstract}

Key words: forest governance, community forestry, collective action, property rights, common-pool resources institutions 


\section{Introduction}

Tropical forest governance has changed profoundly over the last two decades as a result of various concurring processes. Many tropical forest countries reorganized the state and gave lower tiers of government more administrative responsibility and more control over public financial resources. Land and forest tenure reforms brought large areas of forest land under control of indigenous or other long-time resident groups. The same tropical forest countries also reformed legislation that effected forests, the forest sector and people living in forested areas. Researchers, however, have been skeptical about how much these changes have improved democratic natural resource decision making (Andersson et al., 2006; Ribot, 2003). Some unresolved constraints remain the limitations or unwillingness of local governments to involve citizens (Agrawal and Ostrom, 2001; Blair, 2000; Pacheco, 2000), the limited overall performance of local governments (Andersson, 2004), problems arising from the need to address equity and accountability simultaneously (Nygren, 2005), and conflicting overlapping authorities between different tiers of government (Andersson and Ostrom, 2008). In this paper, we analyze local forest governance responses among forest communities in the northern Bolivia Amazon following forestry, land and democratic reforms.

The case of local responses to forest regulatory reforms in Bolivia relates to different academic debates. Since the 1990s Ostrom (1990) and her collaborators began to investigate collective action related to natural resource that are of interest to multiple users, but are difficult to privatize. This research has resulted in a well-developed theoretical body on how local users develop rules and regulations (institutions) and overcome the free rider, c.q. tragedy of the commons syndrome (Hardin, 1969). Some key features are, for instance, design principles for common property resource systems (Ostrom, 1990; 1999; 2009). Key elements are that both resources and the users of the resources need to have a number of attributes for common property resource (CPR) governance arrangements to be able to work acceptably. The robust and long during institutions that eventually are devised by the user groups also have certain common characteristics. This insight, Ostrom (1999) suggest, possibly could be used to actually design natural resource governing institutions in cases where problems of overuse and subsequent deterioration was observed, as was and still is the case in many places where forest dwellers depend for livelihood needs. A critical self-review of the design principles suggest that they hold up reasonably well in the majority of the cases (Ostrom, 2009), but Campbell et al. (2001), among others, suggest that cases from Zimbabwe but also from elsewhere of CPR governance regimes that eventually broke down suggest that the design principles have limited validity in many forest settings.

A second body of literature that is relevant for the case that we investigate is the academic debate on decentralization and its impact on forest dweller communities. Many studies that contribute to this debate departed from the trend in many tropical forest countries in the 1990s of wider national governance reforms that essentially shifted authority and responsibility to lower tiers of government. Decentralization, it was held, would first of all increase efficiency and effectiveness of public administration (Ribot, 2003). Perceived additional benefits are that decentralized government could increase democratization and accountability, both key attributes of what came to be understood as "good governance". One of the main findings of many of the decentralization and local forest user was that decentralization brought the political process that affects forest close to the users, and that this indeed may result in better policies and administration. However, with the exception of a handful of countries, including Bolivia, decentralization as a rule did not increase the legally recognized and protected rights to participate in, for instance, forestry related decision making (Larson et al., 2007).

Academics have tried to link decentralization and local institutional capacity and dynamics with the concept polycentric governance (Anderson and Ostrom, 2008; Nagendra and Ostrom, 2010). Polycentric governance has a normative connotation, as it implies that governance acts, for instance policy, should considers higher and lower governance administrative levels to be more effective and efficient. Anderson and Ostrom (2008: 78) argue that when general rule systems 
designed at higher administrative levels are not fine-tuned to local context, they will weaken local incentives to manage resource responsibly. Hence, polycentric governance is more appropriate to overcome the widely reported limited intended results of decentralization reforms. While the concept of polycentric governance has been explored conceptually, little empirical evidence has been provided of how different polycentric forest governance or more specific forest policies actually affect local institutional dynamics or local capacities and incentives to invest in definition of property rights and related natural resource local rules.

Policy reforms that affect multiple domains are oftentimes broad and contradictory (Pacheco, 2009; Pachecho et al., 2008; Pacheco, 2007; Luoga et al., 2005; Barry and Leigh, 2008) and they require further steps to adequately be implemented at local levels. Communities may opt to adapt customary property rights or customary rules to the new legal framework (Cronkleton et al., 2007; Rist et al., 2007) or may persuade governments to recognize customary rules, even if they contradict the new legal regime (Fitzpatrick, 2005; Gibson et al., 2005). It is not immediately clear whether if CPR institution design principles, or other principles deducted from autonomous institutional solutions to CPR challenges, will also apply in such cases. Until now, yet little evidence has been put forward of how communities resolve internally issues of ownership or use rights when new legislation redefines property rights and procedures to commercially exploit forest resources, as has happened in Bolivia since the mid-1990s.

Considering the above, this paper explores the questions: How do local communities respond to and how do they define their own arrangements under new forest and land regulatory regimes? In particular we seek answers to the questions: How much do such regulatory reforms constrain or enable local capacities to devise local arrangements, and how important and relevant are social, cultural and historical attributes of the communities themselves that need to fend for themselves once forestry reforms have been imposed? We hypothesize that indeed local communities possess capacities to device local institutions to govern common forest resources, and that they can set those capacities to work, for instance when land and forestry regulatory reforms are imposed. However, as the results of our research confirmed, directions that communities take to device these local arrangements is not only influenced by attributes of the CPRs and the forest users, but also by local institutional histories. Even among communities that appear to deal with quite similar CPRs and that share the same cultural attributes and regional history, we observed very different outcomes (Cano, 2012), and this begs for explanation. Thus, we researched responses of forest communities in the northern Bolivian Amazon about 15 years after the country implemented wide-reaching land and forestry reforms which put a large part of the national territory, especially in the tropical forested east and north, under the control of rural villages and indigenous communities, in addition to implementing wide-reaching decentralization and popular participation reforms (Pacheco et al., 2009).

The paper has six sections including this introduction. Section 2 presents the background to Bolivia's decentralization, and agrarian and forestry reforms of the last 15 years. Section 3 summarizes the research methods. Section 4 provides a basic typology of how rural people legitimize former rules and design new ones to distribute land within their community, and to secure access to valuable forest resources. Section 5 suggests some theoretical implications of the empirical findings, and section 6 concludes.

\section{Legal reforms and communities in the northern Bolivian Amazon}

Bolivia's experienced during the mid-1990s wide reaching regulatory reforms. The Popular Participation Law transferred responsibilities and an important share of the national budget directly to municipal governments, and promoted social participation in public administration (Pacheco, 2010). The Administrative Decentralization Law abolished the departmental corporations and transferred their functions to the prefectural government. Both laws gave municipal governments significant responsibilities over public services like health, education, roads, irrigation, 
culture and sports and allocated resources to pay for those services. The laws established local oversight committees, and created many new municipalities (Faguet, 2004). The early decentralization laws, however, had little consequences for forest resource governance (Pacheco, 2009; Andersson et al., 2006; Kaimowitz et al., 1998). Municipalities had limited possibilities to monitor timber harvesting as this was regulated under a different legal regime, and were not allowed to promote local forest initiatives.

Simultaneously, a new land regime considered communal land titles in the Bolivian Amazon as the only feasible option to regularize ownership in communities with complex swidden-fallow and forest use practices (Stoian, 2005; Cronkleton et al., 2009). In the new Communal Redressing of Agrarian Reform Law (2006), communal title has become the only choice for new settlements in the former Brazil nuts estates or barracas. These reforms emphasized collective ownership and resulted in a significant distortion of peoples' customary sense of ownership and tenure (Fitzpatrick, 2005). Specifically for the northern Bolivian Amazon region Government Decree 25848 (2000) imposed that the communal title in the region was granted over an area using the formula of number of families in the community times 500 ha, although in practice there were significant differences among users and regions (e.g. Pando Department vs. Beni Department; Ruiz, 2005).

The government recognized the need of local distribution of land and forest, but established that this should be done according to local uses and customs (usos y costumbres). The new Forest Law, which was part of the mid 1990s regulatory reforms, and its implementing regulations aimed to democratize procedures to benefit from forests that previously were limited to timber companies (Pacheco, 2009; Barry et al., 2010; Kaimowitz et al., 1998). The new forestry law obliged enterprises to exploit timber in forest concessions and granted communities the right to exploit timber and in theory other forest products by preparing forest management plans and annual forest operation plans (Pacheco, 2006). Little thought was given to how communities could comply with the required complicated and expensive formal procedures to that end (Pacheco, 2009). In practice, communities that hold tenure over extensive areas of forest have to negotiate with timber companies, because the latter have the capital, skills and administrative influence (Benneker, 2008; Zenteno, 2013).

\section{Research methods}

The research for this chapter was carried out in the prefectures (Departamentos) of Beni and Pando in the northern Bolivian Amazon, in which two of the main economic activities are Brazil nut harvesting and timber extraction. Until recently the social relationships in the region were reminiscent of the barraca system, a social and spatial organization of rubber and Brazil nut exploitation (Ruiz, 2005). A barraca in northern Bolivia refers to an area of forest that used to be controlled by a wealthy entrepreneur, to which a labor force was attached under debt-peonage arrangements (Cano, 2012; Stoian, 2005).

We selected 16 communities on the basis of the main form of forest resource use (agro-extractives and extractives communities; cf. Stoian and Henkemans, 2000) and the year that the settlements were formally founded. Both characteristics influence the importance of forestry activities and this, should influence the response to forestry and land use legislative reforms. Older communities on average maintain a higher degree a political reality similarly to the time of the barracas (Ruiz 2005). The agro-extractivist communities were located near the regional towns Riberalta and Guayaramerin. While the extractivist communities were located in the former barraca areas, along the Orthon and Manupare rivers. Table 1 shows information on the 16 communities.

We collected information to answer the following specific questions: (1) How did people allocate individual or collective de facto rights about the use of valuable forest resources under collective de jure land and forest rights? (2) Did the legal reforms facilitate or hamper the process of setting individual and collective rights? (3) To what extent did people rely on their customary rules to 
increase benefits from new collective rights granted by recent laws? From October 2008 until April 2010 we used semi-structured interviews to collect information to answer those specific questions. The number of interviews was determined by the principle of information saturation, (Guest et al., 2006). We also interviewed nine professionals and five traders with ample knowledge about the region or about specific communities, resulting in a total of 171 in-depth interviews. Simultaneously to the interviewing, we attended important communal events, for instance, communal assemblies, training events about rules design, and communal natural resource allocation events when they took place. We also interviewed 18 focus groups. We conducted qualitative data analysis (Guest et al., 2006; Brown, 2010) and aimed at identifying patterns and salient themes related to the subject of the research, but also to demonstrate the variation in how social phenomena related to natural resource allocation are framed, articulated, and experienced within institutions formation and rules design.

\section{Results: modalities of land distribution and forest resource rights assignment}

From our analysis we distinguished three modalities of distributing land and granting forest resource rights after communities received collective tenure. In this section we describe those three modalities, which include the rules that communities established internally, and evidence of how these rules were implemented, until the moment that we carried out field research. The modalities differ mostly in terms of rules, assigned rights, and obligations of community members. These are the results mostly of decision taken at communal assemblies, the highest community authority, and in which all household heads are obliged to participate. Decisions are taken by majority votes at community assemblies and recorded. It is the responsibility of the communal board, a legally prescribed communal governance structure with a president, treasurer, secretary and vocals. Table 2 summarizes the three modalities and where they were observed.

\section{Free access forest resource management}

Under the free access forest resource management modality, land distribution is guided by the principle of equitable access to valuable forest resources. Two subtypes of this modality can be distinguished. In the first, the concentration of valuable forest resources in a limited number of locations was the main constraint, and an equal division of land would not guarantee equal access to resources. In the second subtype a more equal distribution of the valuable forest resources occurred, but the resource levels were insufficient to ensure access to equal amounts of resources for all community members. In both subtypes, community members opted for a common land tenure arrangement, and resisted partitioning or assigning forest areas to individual households. Communities developed rules to regulate equal access. Land property rights were held by the entire group, which guaranteed access security for everybody. Individual rights could only be alienated in favor of other community members, but not outsiders, unless there were more resources than the group needed or was able to manage. The rights that could be alienated were over forest resources and not over land per se.

Communities that adopted the free access forest resource management modality developed their own procedures to assign rights. In communities that hold common land tenure in the strictest sense, decisions on access rights were made by the entire community. Access to Brazil nut trees, for instance, followed three simple but consistent rules. One, the community defines every year a common starting date to harvest Brazil nut, and nobody is allowed to start harvesting prior to that day. Two, the amount of Brazil nuts to be harvested depends on a family's capacity. Families that have fewer members than the average family are allowed to hire workers or resort to relatives for help. Three, the allocation of harvest areas to individual families is also decided collectively and can vary from year to year. In some cases there is no allocation of harvest areas and families can choose their own area and trees they want to harvest. In other cases, harvesting areas are being assigned but they rotate randomly between families every harvest season. 
When the opportunity to sell timber occurs, community consensus is required. Without such a consensus, no one takes the initiative. The benefits from timber sales were divided equally and logging is often negotiated with a private timber enterprise that also takes care of the legal procedures. The communal assembly assigned a committee to monitor timber extraction, but most people took part in actually monitoring, sometimes for short periods of time as assigned by the communal assembly. In other cases when the assembly decided to select a permanent monitoring committee, community members helped the committee members with their daily chores, for instance, Brazil nut harvesting or agriculture. Only in case of an economic emergency can community members sell timber independently without communal approval. However, they have to inform the community leaders about the sale.

For other forest products, for instance palm heart (mostly Euterpe precatoria Mart., Stoian, 2005) different rules were applied. In such case, community members were allowed to harvest palm heart for their own consumption or sale. In the latter case, community members were expected to communicate their plans to the communal assembly. They are only allowed occasionally to engage in the collection and sale of any forest product, to assure that resource stocks in the communal forest are not exhausted.

\section{Common-access and individual natural resource management}

The common-access and individual natural resource management modality of assigning land and forest resource access rights is linked to a single valuable forest product, Brazil nut and to agriculture which seems to need different forms of tenure for its access and use. The communities which adopted this modality used to be part of a previous barraca, and barraca workers were assigned a specific Brazil nut forest area for harvesting. The barraca holder assigned those areas considering the estimated amount of Brazil nuts the area could yield, and the distance of the area to the village. The barraca holder favored some workers during this allocation, to create a social hierarchy among workers as a mechanism to maintain control over the workforce (Stoian, 2005). Brazil nut extractive communities with a barraca history opted for this modality of forest access rights. Under this tenure modality there are no locally defined land property rights, only temporary allocations of Brazil nut centers, or locations where Brazil nuts are temporarily stored during the harvest season, a remnant of the organization of harvesting during the barraca era (Stoian, 2005). In these communities, politically powerful families continue to dominate.

In five of the 16 communities family clans within a single community dominated an area that had been part of a different barraca in the past. After the agrarian reform of the 1990s, family clans exercised land rights over communal lands as stipulated by the various laws, but each clan managed its domain following its own rules. Under this modality, rights over Brazil nuts located in a delimited area can be transferred to community members or outsiders, and the current owner takes an autonomous decision to that extent, although the final decision is subject to the communal assembly's deliberations.

For other non-timber forest resources there are often rules that constrain the amount that can be harvested and the purpose of their use. Because Brazil nuts are the most important source of income, people have the right to collect and sell them, sometimes without restrictions, sometimes limiting the quantity of trees that can be harvested by a family and hired collectors. This rule intends to prevent conflicts when collectors hired from outside the village trespass into areas with Brazil nut trees belonging to others, or to prevent community members from invading neighboring Brazil nut areas. The productive potential of each Brazil nut center and a family's labor reserve are the main factors taken into account when Brazil nut areas are assigned, restriction imposed, or compliance with the rules is assessed.

The second 500 hectares Government Decree initially did not accommodate with the common-access and individual natural resource management modality of land distribution and 
resource access. Observing that a distribution of land into 500 ha plots for each family did not ensure equitable access to Brazil nut trees few communities were motivated to initiate a new local land distribution based on former rules. The new approach not only implied a fair natural resource distribution, but also the overcoming of a social power imbalance from the past. In other cases, however, family clans tried to hold on to their power, and control of larger areas of Brazil nut forest, and tried to prevent the innovative local distribution that assured equal access. In some communities more than one family clan struggled to hold on to power and control of land and forest, dividing the community into a number of sub-communities each regulated by their respective dominant clan rules.

In five communities that adopted the common-access and individual natural resource management modality of land and forest resource rights allocation, selling other forest products is not allowed unless it benefits all community members. Collection of forest products for personal consumption is allowed from the area over which rights are held. However, when the opportunity to sell timber occurs, but the village does not come to an agreement, village members often turn to non-authorized selling of timber. As a rule, however, timber is only sold collectively, because the spatial distribution of timber stocks does not allow for a distribution that assures equitable access to all. The income from timber is equally distributed among community members.

\section{Individual tenure and natural resource management}

The individual tenure and natural resource management modality was common within communities that engage in both agriculture and extractive activities, but were established long before the second agrarian reform, and had already adopted individual tenure over land and forest areas with valuable forest products (Stoian and Henkemans, 2000). After the reforms, the communities maintained individual tenure, with clearly defined boundaries between neighboring parcels. Before these communities were legally recognized as a consequence of the second agrarian reform, there were no rules that regulated land acquisition. Interviewees assert that in that time newcomers or residents could freely colonize new land, as long as land belonging to others was respected. These principles were essentially maintained after the communal land titling. While legally the communal land belongs to all community members, there is a marked differentiation of family assets. Currently we found that in some communities family holdings may vary between more than 1000 hectares to only 10 hectares, and yield varies between more than $3000 \mathrm{~kg}$ (\$US 2040) of Brazil nut per year to no Brazil nuts at all. Thus land tenure security rests on the imminent necessity and capacity of individual owners, and is supported by a strong private property rights perception. The sale of land is at the discretion of the owner who communicates any decision to that extent to the community leadership, but not the community assembly. The rights in this case are given for a predefined area of land and for all its natural resource.

Communities with an individually owned natural resource management modality exercised individual property rights, and the distribution of valuable natural resources is subject to land right tenure. The distribution of land and forest resource ownership reflects time of residence in the village, because people who arrived first in the community had the opportunity to select their parcel with valuable forest resources. The right to harvest Brazil nuts or any other kind of non-timber forest product is held by the owner of the land and not the community.

The right to log timber for sale, however, is arranged differently, as the legal status of communal lands obliges community members in principle to prepare a communal forest management plan collectively. Well organized communities prepare and implement such a plan under a solid communal administration, although equity and democratic decision making is much defined by powerful groups. These powerful groups are wealthy households and their direct relatives. Oftentimes these are descendants of previous barraca owners, or of people with powerful positions in the old barracas. Benefits, however, are distributed equally and monitoring is effective. Indeed in some cases, communities blocked unauthorized timber extraction, and forced the 
company engaged in the extraction, to pay when it had infringed on the agreement. Communities that had more difficulties to cooperate internally did elaborate the required forest management plan, but the share of benefits to each community member depended on the timber stock on people's individual plots of land. In the case that communities could not agree to elaborate a collective forest management plan, people used "clearing plans" to log and sell timber, which can be given to individual holders for up to two hectares per year.

\section{Summary of modalities of land distribution and forest resource rights assignment}

Under the free-access forest resource management modality, the individual rights became evident only after people arrange collective rights to land and forest resources. Collective rights are defined to make sure that everybody has the same opportunities. In these communities providing equal conditions to each family group is the single most important standard that defines social relationships, and thus land and forest resource tenure and governance. This modality suggests that people are able to deal with negative consequences of open-access natural resource appropriation, which is in accordance with what was argued by Ostrom (1990; 1999; 2000). Our interpretation is that communities that choose this modality were guided by the key principle that all community members should have the same rights and the only way to assure those rights is by limiting people's individual rights, which forces community members to adjust their own benefit expectations in relation to the resources available and the rights of others.

The common-access and individual forest resource management modality was adopted because it is difficult with one single strategy to adjust for multiple valuable forest resources (Brazil nut and timber). The only way to assure rights related to both timber and non-timber forest products was to define collective and individual rights. The experiences with the former barraca system probably determined why these communities could not easily agree on a singular community forest resource management. From our observation, but also from our interviews from people with insights in social trends in the region, it appears that depending on the presence of dominant family groups, this modality can lead to effective forest resource governance or subject collective and individual rights to the manipulation of powerful groups. In the latter case, when the vertical social structure does not allow for democratic decision-making, especially dominant group members benefit from opportunistic access to valuable forest resources.

In communities in which individual natural resource management prevailed, individual rights were the guiding principle. Although these communities pursued collective forest resource management, this only took place after people have assured their individual property rights. The better these rights were defined, the more likely community members pursued some kind of collective action related to valuable forest resources that are difficult to privatize. When private rights were less clearly defined, people turned to opportunistic behavior, for instance through attracting seasonal harvesters from elsewhere or use forest resources without complying with rules. People also tended to adhere to formal regulations, while ignoring collectively established community rules.

\section{Discussion}

Our results suggest that the new land and forest regulations provided an opportunity for communities in the northern Bolivian Amazon to learn about and take collective action and self-organization. It also forced people to start designing their own communal land and forest resource rights. Under the new reforms, there was less threat of outsiders exploiting communal resources. The threat is now to what extent community members respect or manipulate formal rules that are being imposed through the new regulations, and informal rules that they have devised themselves, to capture benefits when negotiating forest products with outsiders. Community members themselves may also be tempted to use unauthorized or illegal means to harvest and sell forest products for their own advantage, essentially harming the entire community. Informal timber extraction is a clear example of this. The new regime imposes constraints on forest 
resource use, for instance because it demands that communities prepare management plans for timber extraction and in theory similar procedures for Brazil nut extractions. At the same time, however, it provides opportunity and incentives to self-organize. The distribution of land, under different use rights within communities, was the first serious self-organizational step based on local customs, although not always to favor all the community members in the same way, and not always in accordance with formal rules principles.

Our findings suggest that the social and political structure of barracas provided the customary mold on which land distribution under the reform was based, largely influenced by the natural distribution of valuable forest resources. The previous barraca system appears to have influenced the equity and democracy in the distribution of land and access rights to forest resources in communities. Rural people of the region are defining customary rules and this process is still very dynamic and so far seems to have both positive and negative outcomes, when considering the level of democracy, equity and sustainability of the resulting community rules.

According to the above analysis, the following principles influenced communal internal institutional responses and the formulation of rules and their enforcement in the northern Bolivian Amazon. While the legal reforms and related policies define the global framework for land and forest governance, people needed to respond to the reforms within the sphere that is for them to govern. There are multiple factors that explain or determine how single communities respond to the opportunities and the necessity to define natural resource governance within their communal territory after the implementation of the legal and policy reforms. This suggests that new statutory rights, like ownership over land and exclusiveness to benefit from forests on communal land, providing required procedures are followed, do not automatically deliver rights in practice and therefore there is an important hurdle that prevents communities from translating those rights into real benefits using forest resources (Larson et al., 2008). This is also a common feature in, for instance Nicaragua, Guatemala and Brazil (Pacheco et al., 2009). Our findings suggest, however, that in specific circumstances people themselves can find ways to fully exercise the rights bestowed by the government.

Larson et al. (2008) suggest that forest reforms from the last two decades in tropical American countries tried to recognize preexisting customary rights within communities. Our findings, however, suggest that in Northern Bolivia former customary arrangements from the time of barracas were rejected by communities, as being unacceptable. But, these pre-reform arrangements still shape the formation of new community social frameworks, for instance in the form consolidation of dominant groups, principles of land distributions and valuable forest resource allocation. The influence of the latter factors may explain the dynamism of rule design and enforcement and the different configurations of individual and collective choices. The latter is closely related with the confusion generated by the new land and forest reforms, which led people to idealize and even exaggerate the new rights they had received. This poses the question whether regulations hinder (Kaimowitz, 2003) or facilitate (Ostrom, 2000) local productive and sustainable forest management.

Our case studies suggest different forms of how communities adjust collective action, manifested as developing local institutions and rules making, under the influence of new laws. These findings represent an important contribution to our understanding of how people's self-organization around common pool resource governance will evolve, given a particular set of legal reforms and in a particular cultural historical setting. Among the most important aspects observed are the link between self-organization and the ways the new rights related to land and forest become manifest. An important element is that collective action is not separated from private action that aims to benefit of individual rights when those find difficulties to reach recognition at the collective level. When that happens, collective action will be less effective as people will pursue strategies to benefit as much as possible from their share of the collective rights. In this case sustainability, equity and democracy become matters of power and hierarchy in social relations and this may lead 
to a new tragedy of the commons (cf. Hardin, 1968), for instance when powerful groups try to increase benefits which implies limiting opportunities of others. However, when the new rights find acceptance among people, self-organization takes place in order to arrange rules and obtain benefits from collectively managed forest resources, with greater prospects for sustainable exploitation.

In the northern Bolivian Amazon the modifications of the legal an policy reforms that directly affected communal natural resource use created conditions that did not inhibit communities to adjust their local institutions and rules to regulate many aspects of vital natural resources use. Reformed regulatory regimes provide a new reference for the scope of individual and collective rights rendered as collective arrangements. In the Bolivian case, the formal rules and their enforcement were broad and not extremely constraining; they gave communities sufficient space to design arrangements as they best saw fit. The local institutional history, however, strongly conditioned the direction of the local institutional reforms. There was both sufficient space and a local heritage, including negative experiences of powerful entrepreneurs subjecting rural dwellers to exploitative rules. Within single communities, however, because of differences in experiences the outcomes were quite different. More remote communities that had longer been exposed to exploitative regimes by elite families chose different arrangements than communities that already had been exposed to a market economy linked to regional major towns.

This has implications for the concept of polycentric view of natural resource governance (cf. Anderson and Ostrom, 2008; Nahendra and Ostrom, 2012). While it is advisable that the state develops governance arrangement that best adapt to local conditions, its limited capacity to do so can be compensated by communities, when they are left enough room to devise optimal ways to adopt and comply with official regulations. Communities will not necessary lose their capacity to self-regulate under reforms of natural resource governance regimes, providing that the conditions similar to the CPR design principles (Ostrom 1990; 1999; 2009) are not corrupted.

\section{Conclusions}

The tropical forestry sector has seen regulatory reforms in multiple locations world-wide. These reforms have included new legislations to refocus the forestry sector itself, but also legislations that aims to accommodate the role of forests in rural livelihoods or enhance the latter through creating opportunities to capture benefits previously monopolized by the economically powerful. Related trends, like devolution of forest and land ownership or decentralization to allow lower tiers of government to have more control over natural resource policies, including to better accommodate the preferences and needs of forest communities, have had mixed outcomes. There is some general understanding that devolution and decentralization are not sufficient and that subsequent communal self-organization is required for the reforms to take its full effect. This paper provides detailed evidence on how forest communities in northern Bolivia responded to forestry regulatory and policy reforms since the mid-1990s. Under the new regimes communities took matters in their own hands, and designed more specific rules rights and obligations of how community members could and should use economically important forest resources. The cases suggest that communities maintain capacity to prepare their own ownership arrangements and related rules, even if they are strongly conditioned by the regulatory reforms. This suggests that CPR design principles, as suggested by Ostrom (1990; 1999; 2009) remain valid even under the imposition of a new regulatory regime on which communities had little influence. The Bolivian case leaves open the question as to whether new regimes should define more in detail communal forestry institutions, or indeed assume that given the adequate conditions, self-regulation can be relied upon to take care of this. 


\section{References}

Agrawal, A and Gibson, C. (1999). Enchantment and Disenchantment: The Role of Community in Natural Resource Conservation. World Development, 27(4): 629-649.

Agrawal, A and Ostrom, E. (2001). Collective Action, Property Rights, and Decentralization in Resource Use in India and Nepal. Politics Society, 29(4): 485-514.

Agrawal, A. (2007). Forests, Governance, and Sustainability: Common Property Theory and its Contributions. International Journal of the Commons, 1(1): 111-136.

Andersson, K.P and Ostrom, E. (2008). Analyzing Decentralized Resource Regimes from a Polycentric Perspective. Policy Sci, 41(1): 71-93.

Andersson, K.P. (2004). Who Talks with Whom? The Role of Repeated Interactions in Decentralized Forest Governance. World Development, 32(2): 233-249.

Andersson, K.P., Gibson, C.C and Lehoucq, F. (2006). Municipal Politics and Forest Governance: Comparative Analysis of Decentralization in Bolivia and Guatemala. World Development, 34(3): 576-595.

Arnouts, R., Van der Zouwen, M and Arts, B. (2011). Analysing Governance Modes and Shifts Governance Arrangements in Dutch Nature Policy. Forest Policy and Economics, doi:10.1016/j.forpol.2011.04.001

Barry, D and Leigh, T.P. (2008). An Ear to the Ground: Tenure Changes and Challenges for Forest Communities in Latin America. Washington D.C: Rights and Resources Initiative.

Barry, D., Larson, M.A and Colfer J.P. (2010). La Reforma en la Tenencia de los Bosques: Un huérfano que solo tiene tíos. In Anne M. Larson, Ganga Ram Dahal and Carol J. Pierce Colfer (Eds), Bosques y Derechos Comunitarios: Las Reformas a la Tenencia Forestal. Centro para la Investigación Forestal Internacional (CIFOR).

Benneker, C., 2008. Dealing with the state, the market and NGOs. The impact of institutions on the constitution and performance of community forest enterprises in the lowlands of Bolivia. Ph.D. thesis. Wageningen University, Wageningen, Netherlands.

Blair, H. (2000). Participation and Accountability at the Periphery: Democratic Local Governance in Six Countries. World Development, 28(1): 21-39.

Brown, A. (2010). Qualitative Method and Compromise in Applied Social Research. Qualitative Research, 10(2): 229-248.

Campbell, B., A. Mandondo, N. Nemarundwe, B. Sithole, W. de Jong, M. Luckert, F. Matose. 2001. Challenges to proponents of common property resource systems: Despairing voices from the social forests of Zimbabwe. World development, 29 (4): 589-600.

Cano, Walter. 2012. Formal Institutions, Local Arrangements and Conflicts in Northern Bolivian Communities after Forest Governance Reforms. PROMAB Scientific Series, 14. Utrecht, Netherlands.

Cronkleton, P., Gönner, C., Evans, K., Haug M., De Jong, W and Albornoz, M.A. (2007). Supporting Forest Communities in Times of Tenure Uncertainty: Participatory Mapping Experiences from Bolivia and Indonesia. Bangkok, Thailand: Proceedings: International Conference on Poverty Reduction and Forests.

Cronkleton, P., Pacheco, P., Ibergüen, R and Albornoz, M.A. (2009). Reformas en la Tenencia Forestal en Bolivia: La Gestión Comunal en las Tierras Bajas. La Paz, Bolivia: CIFOR/CEDLA.

Dietz, T., Ostrom, E and Stern, P. (2003). The Struggle to Govern the Commons. Science, 302:1907-1912.

Faguet, J.P. (2004). Does Decentralization Increase Government Responsiveness to Local Needs? Evidence from Bolivia. Journal of Public Economics, 88: 867-893.

Fitzpatrick, D. (2005). 'Best Practice' Options for the Legal Recognition of Customary Tenure. Development and Change, 36(3): 449-475.

Gibson, C.C., Williams, J.T and Ostrom, E. (2005). Local Enforcement and Better Forests. World Development, 33(2): 273-284.

Guest, G., Bunce, A and Johnson, L. (2006) How many Interviews are Enough? An Experiment with Data Saturation and Variability. Field Methods, 18(1):59-82. 
Hardin, G. (1968). The Tragedy of the Commons. Science 162 (3859): 1243-1248.

Helmke, G and Levitsky, S. (2004). Informal Institutions and Comparative Politics: A Research Agenda. Perspectives on Politics, 2(4): $725-740$.

Kaimowitz, D., Vallejos, C., Pacheco, P and López, R. (1998). Municipal Governments and Forest Management in Lowland Bolivia. Journal of Environment and Development, 7: 45-59.

Kaimowitz, D. 2003. Forest law enforcement and rural livelihoods. International Forestry Review, 5(3): 199-210.

Larson, A.M., P. Pacheco, F. Toni and M. Vallejo. 2007. Trends in Latin American forestry decentralisations: Legal frameworks, municipal governments and forest dependent groups. International Forestry Review. 9 (73), 734-747.

Larson, A., Barry, D., Cronkleton, P and Pacheco, P. (2008). Tenure rights and beyond: community access to forest resources in Latin America. Occasional Paper No 50. CIFOR, Bogor, Indonesia.

Larson, A.M., Barry, D., Dahal, G.R and Colfer, C.J. (2010). Forests for People: Community Rights and Forest Tenure Reform. Sterling, VA: Earthscan.

Luoga, E.J., Witkowski, E.T.F and Balkwill, K. (2005). Land Cover and Use Changes in Relation to the Institutional Framework and Tenure of Land and Resources in Eastern Tanzania Miombo Woodlands. Environment, Development and Sustainability, 7(1): 71-93.

Nagendra, Harini and Elinor Ostrom (2012) Polycentric Governance of Multifunctional Forested Landscapes. International Journal of the Commons 6(2): 104-133.

Nygren, A. (2005). Community-Based Forest Management within the Context of Institutional Decentralization in Honduras. World Development, 33(4): 639-655.

Ostrom, Elinor (1990). Governing the Commons: The Evolution of Institutions for Collec-tive Action. New York: Cambridge University Press.

Ostrom, E. 1999. Self-governance and forest resources. CIFOR Occasional Paper No 20, Bogor, Indonesia.

Ostrom, E. (2000). Reformulating the commons. Swiss Political Science Review 6(1): $29-52$.

Ostrom, E. (2003). How Types of Goods and Property Rights Jointly Affect Collective Action. Journal of Theoretical Politics, 15(3): 239-270.

Ostrom, E. (2009) Design Principles of Robust Property Rights Institutions: What Have We Learned?" In Property Rights and Land Policies, ed. Gregory K. Ingram and Yu-Hung Hong, 25-51. Cambridge, MA: Lincoln Institute of Land Policy.

Ostrom, E. (2009). A General Framework for Analyzing Sustainability of Social-Ecological Systems. Science, 325(24): 419-422.

Pacheco, D. (2006). Manejo Forestal Comercial Comunitario en Propiedades Colectivas Indígenas de las Tierras Tropicales de Bolivia. La Paz, Bolivia: CERES/IFRI.

Pacheco, D. (2007). An Institutional Analysis of Decentralization and Indigenous Timber Management in Common-Property Areas of Bolivia's Lowlands. PhD Thesis, Indiana University, Bloomington, USA.

Pacheco, P. (2000). Avances y Desafíos en la Descentralización de la Gestión de los Recursos Forestales en Bolivia. CIFOR-BOLFOR, Santa Cruz de la Sierra, Bolivia.

Pacheco, P. (2009). Agrarian Reform in the Brazilian Amazon: Its Implications for Land Distribution and Deforestation. World Development, 37(8): 1337-1347.

Pacheco, P., Barry, D., Cronkleton, P., Larson, A and Monterroso, I. (2008). From Agrarian to Forest Tenure Reforms in Latin America: Assessing their Impacts for Local People and Forests. Cheltenham, Unite Kindom: XXII Conferencia de la Asociación Internacional para el Estudio de la Propiedad Colectiva (IASCP), 14-18 Julio.

Ribot, C.J. (2003). Democratic Decentralization of Natural Resources: Institutional Choice and Discretionary Power Transfer in Sub-Sahara Africa. Public Administration and Development, 23(53): 53-65.

Rist, S., Chidambaranathan, M., Escobar, C., Wiesmann, U and Zimmermann, A. (2007). Moving from Sustainable Management to Sustainable Governance of Natural Resources: The Role of Social Learning Processes in Rural India, Bolivia and Mali. Journal of Rural Studies, 23: 23-37.

Ruiz, A. (2005). Institutional Changes and Social Conflicts Over Forest Use in the Northern Bolivian Amazon. PhD Thesis, Freiburger Schriften zur Forst- und Umweltpolitik (10), Freiburg, Germany. 
Stoian, D and Henkemans, A. (2000) Between Extractivism and Peasant Agriculture: Differentiation of Rural Settlements in the Bolivian Amazon. International Tree Crops Journal, 10: 299-319.

Stoian, D. (2005). La economía Extractivista de la Amazonía Norte de Bolivia. CIFOR, Bogor, Indonesia.

White, A and Martin, A. (2002). Who Owns the World's Forests? Forest Tenure and Public Forest in Transition. Washington, DC: Forests Trends.

Zenteno, Mario. 2013. A Quantitative Analysis of Livelihoods in Community Forestry in the Northern Bolivian Amazon. PROMAB Scientific Series, 15. Utrecht, Netherlands. 
Table 1.Main characteristic of the 16 forest communities related to population,

previous organization type and productive activities

\begin{tabular}{|c|c|c|c|c|c|}
\hline Name & Families & $\begin{array}{l}\text { Dominant } \\
\text { families* }\end{array}$ & $\begin{array}{l}\text { Organization before } \\
\text { reforms }\end{array}$ & $\begin{array}{c}\text { Distance to main } \\
\text { town }\end{array}$ & Main forestry activities \\
\hline \multicolumn{6}{|c|}{ Agro-extractive and old communities } \\
\hline Candelaria & 50 & 3 & Independent settlement & 1.5 hours by road & $\begin{array}{l}\text { Timber and Brazil nut sale, } \\
\text { swidden agriculture }\end{array}$ \\
\hline Campo Central & 26 & 2 & Independent settlement & 30 min by road & $\begin{array}{l}\text { Timber and Brazil nut sale, } \\
\text { swidden agriculture }\end{array}$ \\
\hline Cachuela Mamoré & 53 & 0 & Independent settlement & 20 min by road & Commercial agriculture \\
\hline 12 de Octubre & 70 & 2 & Independent settlement & 30 min by road & $\begin{array}{l}\text { Timber and Brazil nut sale, } \\
\text { swidden agriculture }\end{array}$ \\
\hline Rosario del Yata & 200 & 0 & Independent settlement & 1 hour by road & Commercial agriculture \\
\hline $\begin{array}{l}\text { San Lorenzo de } \\
\text { Pampa }\end{array}$ & 23 & 3 & Independent settlement & $45 \mathrm{~min}$ by road & Commercial agriculture \\
\hline Miraflores & 73 & 0 & Independent settlement & 2 hour by road & $\begin{array}{l}\text { Brazil nut sale, swidden } \\
\text { agriculture }\end{array}$ \\
\hline Warnes & 70 & 0 & Independent settlement & $30 \mathrm{~min}$ by road & $\begin{array}{l}\text { Agriculture, timber sale and } \\
\text { a some Brazil nut sale }\end{array}$ \\
\hline \multicolumn{6}{|c|}{ Extractive and new communities } \\
\hline Las Mercedes & 70 & 3 & Former barraca & $\begin{array}{l}5 \text { hours by road } \\
7 \text { hours by boat }\end{array}$ & Brazil nut sale \\
\hline Remanso & 36 & 2 & Former barraca & $\begin{array}{l}6 \text { hours by road } \\
6 \text { hours by boat }\end{array}$ & Brazil nut sale \\
\hline Península & 13 & 1 & Former barraca & 5 days by boat & Brazil nut sale \\
\hline Ingavi & 23 & 1 & Former barraca & 3 days by boat & Brazil nut and timber sale \\
\hline Santa Fé & 25 & 1 & Former barraca & 5 hours by boat & Brazil nut sale \\
\hline Fortaleza & 27 & 1 & Former barraca & 2.5 days by boat & Brazil nut sale \\
\hline Exaltación & 30 & 1 & Former barraca & 12 hours by road & Brazil nut sale \\
\hline Contravaricia & 36 & 1 & Former barraca & 5 hours by road & Brazil nut and timber sale \\
\hline
\end{tabular}

* Dominant family is a large group of community members linked by acquired or direct family ties. Its strong influence on community issues and decision-making come from having being the first in arrive the community or power given by the patron in the barraca period. 
Table 2a. Rules for land distribution and forest resource access and use among the three modalities observed in the studied communities

\begin{tabular}{|c|c|c|c|c|}
\hline \multirow[b]{2}{*}{ Modality } & \multirow[b]{2}{*}{ Community } & \multicolumn{3}{|c|}{ Inner land distribution } \\
\hline & & Land tenure & $\begin{array}{l}\text { Forms of land } \\
\text { alienation }\end{array}$ & $\begin{array}{l}\text { Agricultural plots } \\
\text { allocation }\end{array}$ \\
\hline $\begin{array}{l}\text { Free access forest } \\
\text { resource } \\
\text { management }\end{array}$ & $\begin{array}{l}\text { Contravaricia/ } \\
\text { Exaltación/ Fortaleza/ } \\
\text { Miraflores }\end{array}$ & $\begin{array}{l}\text { Collective } \\
\text { tenure }\end{array}$ & $\begin{array}{l}\text { Land transaction } \\
\text { (transfer) only or } \\
\text { preferably among } \\
\text { members is a } \\
\text { collective } \\
\text { agreement }\end{array}$ & $\begin{array}{l}\text { Collective area to } \\
\text { agriculture, assigned } \\
\text { randomly every year } \\
\text { based on individual } \\
\text { criteria }\end{array}$ \\
\hline $\begin{array}{l}\text { Common-access and } \\
\text { individual natural } \\
\text { resource } \\
\text { management }\end{array}$ & $\begin{array}{l}\text { Remanso/ Las } \\
\text { Mercedes/ Santa Fé/ } \\
\text { Península/ Ingavi/ } 12 \\
\text { de Octubre }\end{array}$ & $\begin{array}{l}\text { Individual and } \\
\text { collective } \\
\text { tenure }\end{array}$ & $\begin{array}{l}\text { Land transaction } \\
\text { among member or } \\
\text { outsiders with the } \\
\text { permission and } \\
\text { approval of the } \\
\text { community } \\
\text { assembly }\end{array}$ & $\begin{array}{l}\text { Randomly allocation } \\
\text { within a defined } \\
\text { collective area or within } \\
\text { individual Brazil nut } \\
\text { centers/ Collectively and } \\
\text { individual plots of } \\
\text { agroforestry }\end{array}$ \\
\hline $\begin{array}{l}\text { Individual tenure } \\
\text { and natural } \\
\text { resource } \\
\text { management }\end{array}$ & $\begin{array}{l}\text { Warnes/San Lorenzo } \\
\text { de Pampas/ Campo } \\
\text { Central/ Candelaria/ } \\
\text { Cachuela Mamoré/ } \\
\text { Rosario del Yata }\end{array}$ & $\begin{array}{l}\text { Individual } \\
\text { tenure }\end{array}$ & $\begin{array}{l}\text { Land transaction } \\
\text { among member or } \\
\text { with outsiders with } \\
\text { or without the } \\
\text { approval of the } \\
\text { community } \\
\text { assembly }\end{array}$ & $\begin{array}{l}\text { Families define } \\
\text { agricultural plots within } \\
\text { their own parcel based } \\
\text { on own criteria }\end{array}$ \\
\hline
\end{tabular}


Table 2.b. Rules for land distribution and forest resource access and use among the three modalities observed in studied communities

\begin{tabular}{|c|c|c|c|c|c|c|}
\hline \multirow[b]{2}{*}{ Modality } & \multirow[b]{2}{*}{ Community } & \multicolumn{5}{|c|}{ Inner valuable natural resources access and use allocation } \\
\hline & & $\begin{array}{c}\text { Allocation } \\
\text { of brazil } \\
\text { nut } \\
\text { harvest } \\
\text { plots }\end{array}$ & $\begin{array}{l}\text { Formal } \\
\text { modality of } \\
\text { timber use }\end{array}$ & $\begin{array}{l}\text { Informal } \\
\text { modality of } \\
\text { wood use }\end{array}$ & $\begin{array}{l}\text { Modality to } \\
\text { use other } \\
\text { non-timber } \\
\text { forest } \\
\text { products }\end{array}$ & $\begin{array}{l}\text { Rules to } \\
\text { land use } \\
\text { change } \\
\text { for } \\
\text { livestock }\end{array}$ \\
\hline $\begin{array}{l}\text { Free access } \\
\text { forest resource } \\
\text { management }\end{array}$ & $\begin{array}{l}\text { Contravaricia/ } \\
\text { Exaltación/ } \\
\text { Fortaleza/ } \\
\text { Miraflores }\end{array}$ & $\begin{array}{l}\text { Collective } \\
\text { area with } \\
\text { annual } \\
\text { allocation } \\
\text { of Brazil } \\
\text { nut } \\
\text { centers }\end{array}$ & $\begin{array}{l}\text { Forest } \\
\text { management } \\
\text { plan collectively } \\
\text { managed or not } \\
\text { to sell timber } \\
\text { are collective } \\
\text { agreements }\end{array}$ & $\begin{array}{l}\text { Timber sales } \\
\text { only in case } \\
\text { of emergency }\end{array}$ & $\begin{array}{l}\text { Any time } \\
\text { and any } \\
\text { resource for } \\
\text { domestic } \\
\text { use or few } \\
\text { times for } \\
\text { economic } \\
\text { purposes }\end{array}$ & $\begin{array}{l}\text { No } \\
\text { livestock } \\
\text { is a } \\
\text { collective } \\
\text { rule }\end{array}$ \\
\hline $\begin{array}{l}\text { Common-access } \\
\text { and individual } \\
\text { natural resource } \\
\text { management }\end{array}$ & $\begin{array}{l}\text { Remanso/ Las } \\
\text { Mercedes/ } \\
\text { Santa Fé/ } \\
\text { Península/ } \\
\text { Ingavi/ } 12 \text { de } \\
\text { Octubre }\end{array}$ & $\begin{array}{l}\text { Allocation } \\
\text { of } \\
\text { individual } \\
\text { Brazil nut } \\
\text { harvest } \\
\text { based on } \\
\text { the former } \\
\text { barraca } \\
\text { system }\end{array}$ & $\begin{array}{l}\text { No clear } \\
\text { agreements to } \\
\text { sell timber } \\
\text { collectively/No } \\
\text { large-scale } \\
\text { commercial } \\
\text { timber sale/Not } \\
\text { to sell wood as } \\
\text { collective } \\
\text { agreement }\end{array}$ & $\begin{array}{l}\text { Sale of a few } \\
\text { trees } \\
\text { annually from } \\
\text { individual } \\
\text { Brazil nut } \\
\text { centers } \\
\text { leaving a } \\
\text { contribution } \\
\text { to the } \\
\text { community/ } \\
\text { The dominant } \\
\text { groups } \\
\text { normally } \\
\text { monopolize } \\
\text { timber sales }\end{array}$ & $\begin{array}{l}\text { Any } \\
\text { resource for } \\
\text { domestic } \\
\text { purpose } \\
\text { within } \\
\text { individual } \\
\text { Brazil nut } \\
\text { plots only or } \\
\text { for } \\
\text { commercial } \\
\text { purpose } \\
\text { paying taxes } \\
\text { to the } \\
\text { community }\end{array}$ & $\begin{array}{l}\text { Livestock } \\
\text { is allowing } \\
\text { within } \\
\text { individual } \\
\text { Brazil nut } \\
\text { centers. } \\
\text { There is } \\
\text { no rules } \\
\text { to } \\
\text { constrain } \\
\text { this } \\
\text { activity }\end{array}$ \\
\hline $\begin{array}{l}\text { Individual } \\
\text { tenure and } \\
\text { natural resource } \\
\text { management }\end{array}$ & $\begin{array}{l}\text { Warnes/San } \\
\text { Lorenzo de } \\
\text { Pampas/ } \\
\text { Campo } \\
\text { Central/ } \\
\text { Candelaria/ } \\
\text { Cachuela } \\
\text { Mamoré/ } \\
\text { Rosario del } \\
\text { Yata }\end{array}$ & $\begin{array}{l}\text { Brazil nut } \\
\text { harvest } \\
\text { only within } \\
\text { individual } \\
\text { parcels } \\
\text { when this } \\
\text { resource is } \\
\text { available }^{a}\end{array}$ & $\begin{array}{l}\text { When timber is } \\
\text { available in this } \\
\text { communities } \\
\text { the common } \\
\text { way to use it is } \\
\text { through two } \\
\text { hectare clearing } \\
\text { plans }\end{array}$ & $\begin{array}{l}\text { Anyone can } \\
\text { sell timber } \\
\text { individually } \\
\text { without } \\
\text { assembly } \\
\text { approval }\end{array}$ & $\begin{array}{l}\text { Any time } \\
\text { and any } \\
\text { resource for } \\
\text { domestic or } \\
\text { commercial } \\
\text { purposes } \\
\text { without any } \\
\text { permission }\end{array}$ & $\begin{array}{l}\text { Livestock } \\
\text { is allowing } \\
\text { within } \\
\text { individual } \\
\text { parcels. } \\
\text { There is } \\
\text { no rules } \\
\text { to } \\
\text { constrain } \\
\text { this } \\
\text { activity }\end{array}$ \\
\hline
\end{tabular}

a In these communities the existence of brazil nuts is exceptional and naturally poorly distributed. 